\section{Carbon sequestration potential of Hardwickia binata Roxb. based agroforestry in hot semi-arid environment of India: an assessment of tree density impact}

\author{
Dipak Kumar Gupta ${ }^{1, *}$, R. K. Bhatt ${ }^{2}$, \\ Keerthika A. ${ }^{1}$, M. B. Noor mohamed ${ }^{1}$, \\ A. K. Shukla ${ }^{1}$ and B. L. Jangid ${ }^{1}$ \\ ${ }^{1}$ ICAR-Central Arid Zone Research Institute, Regional Research \\ Station, Pali-Marwar 306 401, India \\ ${ }^{2}$ ICAR-Central Arid Zone Research Institute, Jodhpur 342 003, India
}

Agroforestry is one of the most promising options for climate change mitigation through carbon sequestration. However, carbon sequestered in agroforestry system depends on various factors like type of tree species, tree density, system age, soil and climate. One of the most important factors for enhancing carbon sequestration per unit land is tree density. Hardwickia binata Roxb. has been reported as suitable agroforestry tree species with multiple benefits in arid and semi-arid region, however, the role and impact of tree density in carbon sequestration is poorly reported. This study estimated impact of tree density $\left(D_{1}=\right.$ 333 tree $\mathrm{ha}^{-1}$ and $D_{2}=666$ tree $^{-1}$ ) on carbon sequestration potential of 30-year-old $H$. binata Roxb. + Cenchrus setigerus silvipasture system in hot semiarid region of Rajasthan. The carbon sequestered in tree biomass was estimated by reported allometric equations, whereas in soil it was determined by Walkley and Black method. Results showed significant impact of tree density on carbon sequestration per unit tree and per hectare land. The average biomass carbon sequestered by a tree was significantly more $(44.5 \%)$ in low density $\left(D_{1}\right)$ compared to high density $\left(D_{2}\right)$ system. However, total biomass carbon sequestered per hectare land was significantly more $\mathbf{( 4 0 . 8 \% )}$ in high density system (31.6 $\left.\pm 12.6 \mathrm{Mg} \mathrm{C} \mathrm{ha}^{-1}\right)$. Carbon sequestered in soil organic matter was higher in both $D_{1}$ and $D_{2}$ systems compared to control (sole Cenchrus setigerus field). It ranged from $19.93 \pm 0.31 \mathrm{Mg} \mathrm{C} \mathrm{ha}^{-1}$ in control to $22.94 \pm 0.65 \mathrm{Mg} \mathrm{Cha}^{-1}$ and $23.25 \pm$ $0.78 \mathrm{Mg} \mathrm{C} \mathrm{ha}^{-1}$ in $D_{1}$ and $D_{2}$ respectively. The total carbon sequestered (below and above ground tree biomass and soil organic carbon) was in the order $D_{2}>D_{1}>$ control.

Keywords: Agroforestry, allometric equation, arid and semiarid regions, silvipasture, C-sequestration, tree density.

GLOBAL warming and associated climate change is negatively impacting humans and almost all ecosystems on the earth. The main cause of this change is rapid increase

\footnotetext{
*For correspondence. (e-mail: dipakbauiari@gmail.com)
}

in greenhouse gases (GHG) especially $\mathrm{CO}_{2}, \mathrm{CH}_{4}$ and $\mathrm{N}_{2} \mathrm{O}$ and their atmospheric concentration which has increased by $40 \%, 150 \%$ and $20 \%$ respectively, since 1750 (ref. 1). Out of these $\mathrm{GHG}, \mathrm{CO}_{2}$ concentrations are increasing at the fastest observed decadal rate of change $(2.0 \pm$ $0.1 \mathrm{ppm} \mathrm{y}^{-1}$ for 2002-2011) and is the largest single contributor to global warming (>70\%) over 1750-2011 (ref. 1). Reducing atmospheric concentration of $\mathrm{CO}_{2}$ is the need of the hour for slowing down global warming and climate change. Agroforestry system has been reported as the most suitable option for achieving sustainable livelihood, climate change mitigation and adaptation. This land use system helps in mitigating climate change by sequestering large amount of $\mathrm{CO}_{2}$ in the form of tree biomass and soil organic carbon (SOC) while also providing benefits like soil erosion control, modification of micro climate and production of resources like fodder, fuel, fruit, fibre and wood, etc. ${ }^{2-4}$.

In India, carbon sequestration potential of agroforestry systems is estimated as $0.25-76.55 \mathrm{Mg} \mathrm{C} \mathrm{ha}^{-1} \mathrm{yr}^{-1}$ for tree and $3.98 \mathrm{Mg} \mathrm{C} \mathrm{ha}^{-1} \mathrm{yr}^{-1}$ for $\mathrm{SOC}^{4}$. However, this potential varies with region, types of species, age of agroforestry system, environmental condition, and previous land use history ${ }^{4,5}$. Livelihood of most of the farmers of arid and semi-arid region of India mainly depends on rain-fed agriculture and animal husbandry. Scarcity of fodder due to harsh climatic conditions in these regions is a major problem for farmers depending on animal husbandry. Silvipasture system becomes the most important intervention for sustainable animal husbandry in this region. Hardwickia binata Roxb. is a leguminous tree and is reported to enhance land use efficiency and fulfil multiple demands (timber, fodder and fuel) in arid and semiarid regions ${ }^{6,7}$. H. binata Roxb. based silvipasture system has also reported to sequester carbon at the rate of 2.24$3.44 \mathrm{Mg} \mathrm{C} \mathrm{ha}^{-1} \mathrm{yr}^{-1}$ (refs 4, 8, 9). However, tree density is one of the major factors that directly affects yield of inter-cropped species and tree biomass production/ carbon sequestration under agroforestry system ${ }^{10-12}$. Further, optimum tree density for getting maximum yield of intercropped species differs with age of the agroforestry system. Under Prosopis cineraria based agroforestry system, 278 and 208 trees $^{-1}$ have been reported as the optimum tree density at the age of 6-7 years and 10-11 years respectively, for obtaining maximum intercrop yield $^{10}$.

Under $H$. binata Roxb. based agroforestry system, previous studies mainly focused on quantifying impact on intercrop, biomass production and soil quality. However, impact of tree density of $H$. binata Roxb. based agroforestry on carbon sequestration in tree biomass and soil has not been reported especially in arid regions. Furthermore, quantifying carbon sequestration potential of a tree species requires conduction of a long duration experiment. Comparing carbon sequestered in already existing old-age/matured agroforestry systems may provide good 


\section{RESEARCH COMMUNICATIONS}

Table 1. Allometric equations used in estimating tree biomass and biomass carbon stock

\begin{tabular}{|c|c|c|c|c|c|c|}
\hline Components & Equation & $R^{2}$ & M.S.E. & $P$ value & Reference & Symbol \\
\hline Total biomass (TB) & $0.158(\mathrm{DBH})^{2.349}$ & 0.99 & - & - & 8 & E1 \\
\hline Root biomass (RB) & $0.036(\mathrm{DBH})^{2.3237}$ & 0.99 & - & - & & \\
\hline Total biomass (TB) & $0.0938(\mathrm{DBH})^{2.5247}$ & 0.95 & 48.8 & $<0.0001$ & 14 & E2 \\
\hline Root biomass & $0.0157(\mathrm{DBH})^{2.5726}$ & 0.85 & 6.02 & $<0.0001$ & & \\
\hline Above ground biomass-C (\%) & $46 \%$ of $\mathrm{AGB}$ & & & & 8 & \\
\hline Below ground biomass-C (\%) & $45 \%$ of $\mathrm{RB}$ & & & & & \\
\hline
\end{tabular}

opportunity for identifying agroforestry systems with high carbon sequestration potential in a short duration of time. More time can be saved by switching from direct destructive estimation to an indirect method like the use of allometric equations ${ }^{13}$. With this background, the objectives of the study were: (i) to determine the amount of carbon sequestered in biomass and soil in 30-year-old $H$. binata Roxb. based silvipasture systems under hot semiarid environment of India and (ii) to quantify the impact of different tree densities on carbon sequestration and yield of intercrop species. This work aims to utilize old planted agroforestry system for better understanding of impact of tree density on carbon sequestration in matured stage of the agroforestry system.

The study was conducted in hot semi-arid environment of India, at ICAR-Central Arid Zone Research Institute, Regional Research Station (Pali-Marwar, Rajasthan) for estimating carbon sequestration in 30-year-old $H$. binata Roxb. based silvipasture system. The research station is located between $25^{\circ} 47^{\prime}-25^{\circ} 49^{\prime} \mathrm{N}$ and $73^{\circ} 17^{\prime}-73^{\circ} 18^{\prime} \mathrm{E}$ at $217-220 \mathrm{~m}$ amsl and receives $460 \mathrm{~mm}$ annual average rainfall with annual maximum mean temperature of $42^{\circ} \mathrm{C}$ and minimum $7^{\circ} \mathrm{C}$. The soils were shallow in depth $(30$ $45 \mathrm{~cm}$ ) with sandy clay loam to sandy loam texture, 1.35 $1.5 \mathrm{Mg} \mathrm{m}^{-3}$ bulk density, $7.7-8.4 \mathrm{pH}, 0.15-0.55 \mathrm{dSm}^{-1}$ electrical conductivity and a dense underlying layer of murrum (highly calcareous weathered granite fragment coated with lime).

$H$. binata Roxb. intercropped with $C$. setigerus silvipasture systems with two tree densities, i.e. $D_{1}$ (333 tree ha ${ }^{-1}$ with $10 \times 3 \mathrm{~m}$ spacing) and $D_{2}$ (666 tree ha ${ }^{-1}$ with $5 \times 3 \mathrm{~m}$ spacing) were established in two replications at the station in July 1986. Each replication contained five rows of trees in $D_{1}$ and seven rows in $D_{2}$ with 21 trees in each row. Carbon sequestered in these 30 -year-old systems were estimated by two reported allometric equations for estimating biomass of $H$. binata Roxb. grown in arid and semi-arid environment (Table $1)^{8,14}$. In January 2017 , total number, diameter at breast height (DBH) and height of the $H$. binata Roxb. trees were recorded manually with measuring tape and height pole respectively from all rows except boundary rows and two trees on both the ends of each row to avoid boundary effect. Observations were avoided for trees with gap (due of loss of tree) to simulate similar effect of tree density.
The total biomass carbon sequestered per hectare area was calculated on the basis of survival percentage of trees in the experiment. After flowering, above ground biomass of C. setigerus was harvested in 2016 and 2017 from three randomly selected plots $\left(3 \mathrm{~m} \times 10 \mathrm{~m}\right.$ in $D_{1}$ and $3 \mathrm{~m} \times 5 \mathrm{~m}$ in $D_{2}$ ) within each inter-row space (except boundary inter-row space) for comparing dry matter yield.

Composite soil samples of three randomly sampled soils from 0 to $30 \mathrm{~cm}$ depth in each inter row space were collected for determining SOC. Each soil sample was collected near the base and $2.5 \mathrm{~m}$ and $5 \mathrm{~m}$ away from tree base in $D_{1}$ and $D_{2}$ systems. Boundary rows were avoided for the collection of soil samples. Additional soil samples from $0-30 \mathrm{~cm}$ depth were also randomly collected from adjoining $C$. setigerus field (control) for comparing amount of SOC sequestered under $D_{1}$ and $D_{2}$ systems. SOC was determined by estimating easily oxidizable organic carbon in composite soil samples by wet oxidation method as outlined by Walkley and Black ${ }^{15}$. Three soil cores $(10 \mathrm{~cm}$ depth) were randomly collected at $0-10$, 10-20 and 20-30 cm depth from each inter-row space in $H_{1}$ and $H_{2}$ systems as well as in control for determining soil bulk density by the method outlined by Black ${ }^{16}$. Further, the organic carbon sequestered in soil in $0-30 \mathrm{~cm}$ depth was calculated as follows

$$
\begin{aligned}
& \text { SOC stock }\left(\mathrm{mg} \mathrm{C} \mathrm{ha}^{-1}\right)=\operatorname{SOC}(\%) \\
& \times \text { Bulk density }\left(\mathrm{g} \mathrm{cm}^{-3}\right) \times \text { Sampling depth }(\mathrm{cm}) .
\end{aligned}
$$

Mean of tree growth parameters, tree biomass and tree biomass carbon of both the systems $\left(D_{1}\right.$ and $\left.D_{2}\right)$ were compared by independent $t$-test while SOC stock and grass yield among $D_{1}, D_{2}$ and control were compared by Duncan multiple range test (DMRT). All the statistical analysis was performed at 95\% confidence level.

Total tree biomass (stem + root) as well as below ground tree biomass (root) estimated from both the allometric equations were slightly different, but this difference was insignificant (Table 2). Difference in below ground biomass (BGB) was almost consistent for all DBH ranges while for total biomass (TB) minimum difference was obtained for 19-20 cm DBH; beyond this, the difference increased towards both ends (Table 2). Considering a slight difference in the estimated result of 
RESEARCH COMMUNICATIONS

Table 2. Independent sample $t$-test of biomass obtained from allometric equations

\begin{tabular}{|c|c|c|c|c|c|c|c|}
\hline Agroforestry system & Biomass & $\begin{array}{l}\text { Allometric } \\
\text { equation }\end{array}$ & $\begin{array}{c}\text { Mean } \\
\left(\mathrm{kg} \mathrm{tree}^{-1}\right)\end{array}$ & $\mathrm{SD}$ & $P$ value & $\begin{array}{c}\text { Mean } \\
\text { difference }\end{array}$ & $\begin{array}{l}\text { Std error } \\
\text { difference }\end{array}$ \\
\hline \multirow[t]{4}{*}{$\mathrm{D} 1(10 \times 3 \mathrm{~m})$} & Total biomass (TB) & E1 & 253.83 & 103.67 & 0.7 & -9.55 & 24.58 \\
\hline & & E2 & 263.38 & 115.83 & & & \\
\hline & Below ground biomass (BGB) & E1 & 53.37 & 21.56 & 0.69 & 2.03 & 4.99 \\
\hline & & E2 & 51.34 & 23.02 & & & \\
\hline \multirow[t]{3}{*}{$\mathrm{D} 2(5 \times 3 \mathrm{~m})$} & Total biomass (TB) & E1 & 178.06 & 68.35 & 0.9 & -1.77 & 14.25 \\
\hline & Below ground biomass (BGB) & E1 & 37.58 & 14.28 & 0.34 & 2.79 & 2.89 \\
\hline & & E2 & 34.8 & 14.59 & & & \\
\hline
\end{tabular}

SD, Standard deviation.

Table 3. Tree biomass production and carbon stock in biomass and soil of the silvipasture systems

\begin{tabular}{|c|c|c|c|c|c|c|c|}
\hline \multirow[b]{2}{*}{ Silvipasture system } & \multirow{2}{*}{$\begin{array}{c}\text { Pasture } \\
\text { AGB yield } \\
\left(\mathrm{Mg} \mathrm{ha}^{-1}\right)\end{array}$} & \multirow{2}{*}{$\begin{array}{c}\text { Total biomass } \\
\text { stock per tree } \\
(\mathrm{AGB}+\mathrm{BGB}) \\
\left.(\mathrm{kg} \mathrm{tree})^{-1}\right)\end{array}$} & \multicolumn{2}{|c|}{$\begin{array}{l}\text { Total tree biomass carbon } \\
\text { stock }(\mathrm{AGB}+\mathrm{BGB})\end{array}$} & \multicolumn{2}{|c|}{$\begin{array}{c}\mathrm{CO}_{2} \text { sequestration potential } \\
\text { in tree biomass }\end{array}$} & \multirow{2}{*}{$\begin{array}{l}\text { Soil organic } \\
\text { carbon stock } \\
\left(\mathrm{Mg} \mathrm{C} \mathrm{ha}^{-1}\right)\end{array}$} \\
\hline & & & $\mathrm{kg} \mathrm{C}$ tree $^{-1}$ & $\mathrm{Mg} \mathrm{C} \mathrm{ha}^{-1}$ & $\begin{array}{l}\mathrm{Mg} \mathrm{CO}_{2} \\
\mathrm{ha}^{-1} \mathrm{y}^{-1}\end{array}$ & $\begin{array}{l}\mathrm{Mg} \mathrm{CO}_{2} \mathrm{ha}^{-1} \\
\text { in } 30 \text { years }\end{array}$ & \\
\hline $\mathrm{D}_{1}(10 \times 3 \mathrm{~m})\left(333\right.$ tree ha $\left.{ }^{-1}\right)$ & $1.67 \pm 0.14 b$ & $258.6 \pm 109.75$ & $118.44 \pm 50.26$ & $22.48 \pm 9.5$ & $2.75 \pm 1.16$ & $82.4 \pm 34.8$ & $22.94 \pm 0.65 \mathrm{a}$ \\
\hline $\mathrm{D}_{2}(5 \times 3 \mathrm{~m})\left(666\right.$ tree ha $\left.^{-1}\right)$ & $1.57 \pm 0.08 b$ & $178.95 \pm 71.2$ & $81.96 \pm 32.61$ & $31.66 \pm 12.6$ & $3.87 \pm 1.5$ & $116.1 \pm 46.2$ & $23.25 \pm 0.78 \mathrm{a}$ \\
\hline$P$ value & 0.007 & $<0.001$ & $<0.001$ & $<0.001$ & $<0.001$ & $<0.001$ & 0.001 \\
\hline
\end{tabular}

Below ground biomass (BGB), above ground biomass (AGB).

$* P$ value: of independent $t$-test for equality of means (tree biomass carbon) between trees of spacing $5 \times 3 \mathrm{~m}$ and $10 \times 3 \mathrm{~m}$ at $\alpha=0.05$.

** Mean value followed by same alphabet in soil organic carbon group are insignificantly different according to DMRT at $P=0.05$.

both equations, mean of biomass obtained from these two equations was used to estimate biomass C-stock.

Both systems showed similar survival percentage and about $57 \%$ of trees survived in $D_{1}$ while $58 \%$ survived in $D_{2}$ system. The average number of trees that survived in each row was $12 \pm 1.87$ and $12.14 \pm 2.41$ in $D_{1}$ and $D_{2}$ system respectively. The DBH $(19.57 \pm 0.46 \mathrm{~cm})$ and height $(8.42 \pm 0.12 \mathrm{~m})$ were significantly higher $(16 \%$ and $7.5 \%$ respectively) in low tree density $\left(D_{1}\right)$ as compared to high tree density $\left(D_{2}\right)$ system. This led to significantly higher $(44.5 \%)$ tree biomass carbon in low tree density system $\left(118.44 \pm 50.26 \mathrm{~kg} \mathrm{C}\right.$ tree $\left.^{-1}\right)$ compared to high tree density system $\left(81.96 \pm 32.61 \mathrm{~kg} \mathrm{C}^{-1}\right.$ tree $\left.^{-1}\right)$ (Table 3 ). In spite of higher biomass carbon stock per tree in low density agroforestry system, tree biomass carbon stock per hectare was significantly higher $(40.8 \%)$ in high tree density system $\left(31.66 \pm 12.6 \mathrm{Mg} \mathrm{Cha}^{-1}\right)$ compared to low tree density system $\left(22.48 \pm 9.5 \mathrm{Mg} \mathrm{C} \mathrm{ha}^{-1}\right)$ (Table 3). $D_{1}$ and $D_{2}$ system sequestered about $82.4 \pm 34.8 \mathrm{Mg} \mathrm{CO}_{2} \mathrm{ha}^{-1}$ and $116.1 \pm 46.2 \mathrm{Mg} \mathrm{CO}_{2} \mathrm{ha}^{-1}$ respectively, in 30 years with annual sequestration potential of $2.75 \pm 1.16 \mathrm{Mg} \quad \mathrm{CO}_{2} \mathrm{ha}^{-1} \mathrm{yr}^{-1}$ and $3.87 \pm$ $1.54 \mathrm{Mg} \mathrm{CO}_{2} \mathrm{ha}^{-1} \mathrm{yr}^{-1}$ respectively (Table 3). The dry biomass yield of $C$. setigerus was about $30 \%$ less in both $D_{1}$ and $D_{2}$ compared to sole $C$. setigerus field (2.33 $\mathrm{Mg} \mathrm{ha}^{-1}$ ) (Table 3). However, there was insignificant difference in dry biomass yield between both systems $\left[D_{1}\right.$ $\left(1.67 \mathrm{Mg} \mathrm{ha}^{-1}\right)$ and $\left.D_{2}\left(1.57 \mathrm{Mg} \mathrm{ha}^{-1}\right)\right]$ indicating $D_{2}$ sys- tem has significantly higher tree biomass carbon sequestration potential per hectare land without significant reduction in C. setigerus dry biomass yield.

Both silvipasture systems showed insignificant difference in SOC stock $\left(D_{1} 22.94 \pm 0.65 \mathrm{Mg} \mathrm{C} \mathrm{ha}^{-1}\right.$ and $D_{2}$ $\left.23.25 \pm 0.78 \mathrm{Mg} \mathrm{C} \mathrm{ha}^{-1}\right)$; however, both had significantly higher SOC-stock (15.8\%) compared to control (19.93 \pm $0.31 \mathrm{Mg} \mathrm{C} \mathrm{ha}^{-1}$ ) (Table 3 and Figure 1) in $0-30 \mathrm{~cm}$ soil depth. There was significant difference in total carbon sequestration (biomass + soil) among $\mathrm{D}_{1}, \mathrm{D}_{2}$ and control. The total carbon sequestered per hectare land was highest in $D_{2}\left(54.8 \pm 5.6 \mathrm{Mg} \mathrm{Cha}^{-1}\right)$ followed by $D_{1}(45.5 \pm$ $4.3 \mathrm{Mg} \mathrm{C} \mathrm{ha}^{-1}$ ) and sole C. setigerus field (19.93 \pm $0.31 \mathrm{Mg} \mathrm{C} \mathrm{ha}^{-1}$ ) (Figure 1). In $D_{1}$, carbon sequestered in biomass and soil was almost similar, while in $D_{2}$, carbon sequestered in biomass was more compared to soil (Figure 1). The contribution of $\mathrm{AGB}, \mathrm{BGB}$ and soil in total carbon sequestration was $40 \%, 10 \%$ and $50 \%$ in $D_{1}$ and $46 \%, 12 \%$ and $42 \%$ in $D_{2}$ respectively (Figure 1).

Higher growth and biomass carbon of individual tree in low density system $\left(D_{1}\right)$, compared to high density $\left(D_{2}\right)$ may be due to less competition for resources like water, nutrients and/or low shading effect of adjoining tree row. Agroforestry system with high tree density has reported lower tree growth, tree biomass and inter crop yield compared to low density system mainly due to competition for resources ${ }^{6,10-12}$. However, high tree density system produced more tree biomass per hectare area compared to 
low density system due to more number of trees per unit area. This indicates that an individual tree may sequester more biomass carbon in low density plantation; however, total biomass carbon stored per hectare area depends on tree density. Therefore, optimum tree density is required for highest gain for both, tree biomass as well as yield of intercrop. In the present study, total tree biomass yield was $258.60 \pm 109.75 \mathrm{~kg}^{-1} \mathrm{tree}^{-1}$ in low density system $\left(333\right.$ tree ha $^{-1}$ ) while $178.95 \pm 71.20 \mathrm{~kg} \mathrm{tree}^{-1}$ in high density system $\left(666\right.$ tree ha $\left.^{-1}\right)$. However, Singh and $\operatorname{Singh}^{14}$ reported relatively lower, i.e., $42 \pm 31 \mathrm{~kg}^{\text {tree }}{ }^{-1}$ total (below and above) biomass in 17-year-old $H$. binata based agroforestry system with density of 400 tree ha $^{-1}$ in arid zone; while, Newaj et al. $^{8}$ reported relatively higher, i.e. $505 \pm 15 \mathrm{~kg}^{-1} \mathrm{tree}^{-1}$ in 20 -year-old system with density of 200 tree ha $^{-1}$ in semi-arid zone. Similar kinds of differences were also observed for total biomass carbon stock. Under $D_{1}$ and $D_{2}$ system, total biomass carbon stock was $22.5 \pm 9.5 \mathrm{Mg} \mathrm{Cha}^{-1}$ and $31.6 \pm 12.6 \mathrm{Mg} \mathrm{Cha}^{-1}$ in $D_{1}$ and $D_{2}$ system respectively, after 30 years of establishment; whereas, Newaj et al. ${ }^{8}$ reported relatively higher biomass carbon sequestration $\left(46.13 \pm 1.42 \mathrm{Mg} \mathrm{C} \mathrm{ha}^{-1}\right)$ in only 20-year-old system with density of 200 tree ha $^{-1}$ in semi-arid zone. This difference might be due to differences in climatic condition, as Singh and $\operatorname{Singh}^{14}$ reported a study from an arid region with relatively low mean annual rainfall $(350 \mathrm{~mm})$ and Newaj et al. ${ }^{8}$ reported a study from a semi-arid region with relatively higher mean annual rain fall $(958 \mathrm{~mm})$.

The SOC stock in this study ranged from $19.93 \mathrm{Mg} \mathrm{Cha}^{-1}$ in control, to $22.94 \mathrm{Mg} \mathrm{Cha}^{-1}$ and $23.25 \mathrm{Mg} \mathrm{C} \mathrm{ha}^{-1}$ in $D_{1}$ and $D_{2}$ system respectively. Dhyani et $a .^{17}$ also reported 4.28 to $24.13 \mathrm{Mg} \mathrm{C} \mathrm{ha}^{-1} \mathrm{SOC}$ stock under existing agroforestry systems (tree density 1.81 to 204 tree ha $^{-1}$ ) in different parts of India. In this study, under both density systems $\left(D_{1}\right.$ and $\left.D_{2}\right)$, organic carbon stock $(0-30 \mathrm{~cm}$ soil profile) was significantly higher $(15.8 \%)$ than sole pasture (C. setigerus) field (control). Positive impact of agroforestry on soil carbon
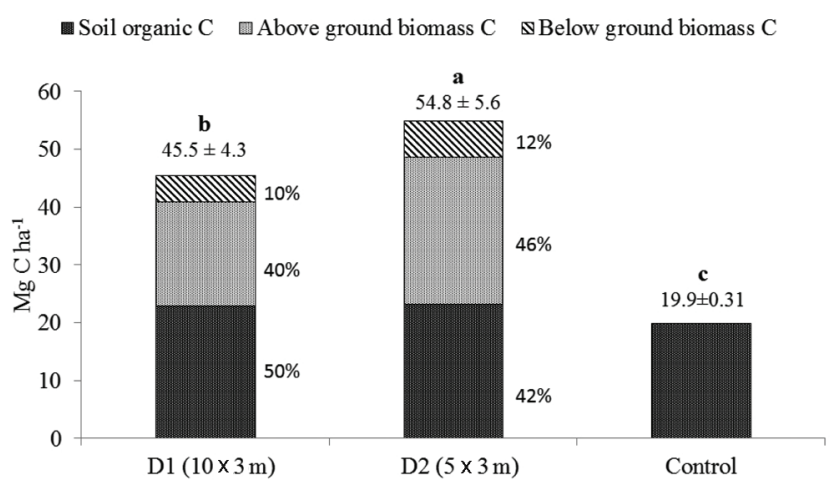

Figure 1. Distribution of carbon stock in different components of agroforestry system. Note: Column with different alphabets on top is significantly different according to DMRT at $P=0.05$. sequestration has also been reported in many studies in India and other parts of the world ${ }^{18-21}$. In the arid region of Gujarat (India), SOC stock under 15-year-old silvipastoral system (Acacia tortilis/Azadirachta + Cenchrus ciliaris/C. setigerus) was reported to be $27.1-70.8 \%$ more compared to the sole pasture system $(C$. ciliaris and $C$. setigerus) in $0-100 \mathrm{~cm}$ soil profile ${ }^{18}$. In Kerala (India), home gardens with higher number of plant species and tree density have reported higher soil carbon, especially in the top $50 \mathrm{~cm}$ of soil $\left(61.5 \text { to } 73 \mathrm{Mg} \mathrm{C} \mathrm{ha}^{-1}\right)^{19}$. The higher level of SOC stock under agroforestry system may be due to addition of leaf litter from tree, low soil erosion and modification in microclimatic condition ${ }^{22-25}$. In addition to climatic effects, modification in soil microclimate due to shading effect of trees may also influence decomposition and sequestration of SOC. Surface soils are generally cooler and drier under plantations than under pasture due to shading and high transpiration ${ }^{25}$. This factor might contribute to slower decomposition rates following tree plantation. Further, accumulation of soil carbon was reported to be the greatest, when deciduous hard woods or $\mathrm{N}_{2}$-fixing species were established on excropped land in tropical or subtropical regions ${ }^{25}$. Further, in more than 30-year-old plantations, SOC stock has been reported to be similar to that under the previous land use system (agriculture) within top $10 \mathrm{~cm}$ of soil, however at other sampling depths, it has been reported to increase from $0.50 \%$ to $0.86 \%$ per year.

The study found significant effect of tree density on carbon sequestration in agroforestry system. A system with high tree density had less C-accumulation in an individual tree compared to a low density system; however, total carbon sequestered per hectare area was significantly more in a high density tree system. Tree spacing has also been reported to affect the yield of intercrop as well as tree due to competition and shade effect, which increases with the age of system. Therefore, determination of optimum tree density is necessary for getting maximum benefits in terms of carbon sequestration, intercrop and tree yield. In this study, established old agroforestry systems with different tree densities provide a good platform for determining carbon sequestration potential along with identification of better tree density for climate change mitigation and adaptation. In this, study $H$. binnata Roxb. based agroforestry system with high density (666 tree ha $\mathrm{h}^{-1}$ ) was found suitable for enhancing carbon sequestration per hactare land over low density system and sole crop land. This system can sequester about $116.1 \pm 46.2 \mathrm{Mg} \mathrm{CO}_{2} \mathrm{ha}^{-1}$ in biomass with $58 \%$ survival rate in 30 years.

1. Core Writing Team, Pachauri, R. K. and Meyer, L. A. (eds), IPCC Climate Change 2014: Synthesis Report. Contribution of Working Groups I, II and III to the Fifth Assessment Report of the Intergovernmental Panel on Climate Change, IPCC, Geneva, Switzerland, 2014 , p. 151. 
2. Verchot, L. V. et al., Climate changes: linking adaptation and mitigation through agroforestry. Mitig. Adapt. Strat. Gl. Change, 2007, 12, 901-910.

3. Koohafkan, P., Altieri, A. M. and Gimenez, H. E., Green Agriculture: foundations for biodiverse, resilient and productive agricultural systems. Int. J. Agric. Sustain., 2012, 10, 61-75.

4. Dhyani, S. K., Ram, A. and Dev, I., Potential of agroforestry systems in carbon sequestration in India. Indian J. Agric. Sci., 2016, 86, 1103-1112.

5. Kaul, M., Mohren, G. M. J. and Dadhwal, V. K., Carbon storage and sequestration potential of selected tree species in India. Mitig. Adapt. Strat. Gl. Change, 2010, 15, 489-510.

6. Shanker, A. K., Newaj, R., Rai, P., Solanki, K. R., Kareemulla, K., Tiwari, R. and Ajit, Microclimate modifications, growth and yield of intercrops under Hardwickia binata Roxb. based agroforestry system. Arch. Agron. Soil Sci., 2005, 51, 253-268.

7. Singh, G. and Rathod, T. R., Tree and crop growth and soil resource availability in Hardwickia binata Roxb agroforestry systems in the Indian desert. Arid Land Res. Manage., 2007, 21, 193210 .

8. Newaj, R., Chavan, S. B., Alam, B. and Dhyani, S. K., Biomass and carbon storage in trees grown under different agroforestry systems in semi-arid region of Central India. Indian Forester, 2016, 142, 642-648.

9. Rai, P., Solanki, K. R. and Singh, U. P., Growth and biomass production of multipurpose tree species in natural grass land under semi-arid condition. Indian J. Agroforest., 2000, 2, 101-103.

10. Misra, K. K., Rai, P. N. and Jaiswal, H. R., Effect of spacing and plant density on the growth of poplar (Populus deltoides Bartr. Ex Marsh). Indian Forester, 1996, 122, 65-68.

11. Silva, P. S. L. et al., Biomass of tree species as a response to planting density and interspecific competition. Revista Árvore, 2014, 38, 319-329.

12. Singh, G., Mutha, S. and Bala, N., Effect of tree density on productivity of a Prosopis cineraria agroforestry system in North Western India. J. Arid Environ., 2007, 70, 152-163.

13. Chave, J. et al., Improved allometric models to estimate the aboveground biomass of tropical trees. Global Change Biol., 2014, 20, 3177-3190.

14. Singh, G. and Singh, B., Rooting pattern and equations for estimating biomasses of Hardwickia binata and Colophospermum mopane trees in agroforestry system in Indian desert. Research and reviews. J. Bot. Sci., 2015, 4, 30-40.

15. Walkley, A. and Black, I. A., An examination of the Degtjareff method for determining soil organic matter, and proposed modification of the chromic acid titration method. Soil Sci., 1934, 37, 29-38.

16. Black, C. A., Methods of Soil Analysis Part 1, American Society of Agronomy, Madison, Wisconsin, USA, 1965.

17. Dhyani, A. S. K. et al., Estimating carbon sequestration potential of existing agroforestry systems in India. Agroforest. Syst., 2017, 91, 1101-1118.

18. Mangalassery, S., Dayal, D., Meena, S. L. and Ram, B., Carbon sequestration in agroforestry and pasture systems in arid north western India. Curr. Sci., 2014, 107(8), 1290-1293.

19. Saha, S. K., Nair, P. K. R., Nair, V. D. and Kumar, B. M., Soil carbon stock in relation to plant diversity of homegardens in Kerala, India. Agroforest. Syst., 2009, 76, 53-65.

20. Beckert, M. R., Smith, P., Lilly, A. and Chapman, S. J., Soil and tree biomass carbon sequestration potential of silvopastoral and woodland-pasture systems in North East Scotland. Agroforest. Syst., 2016, 90, 371-383.

21. Mansor, P. R., Vieira, H. D., Rangel, O. J. P., Partelli, F. L. and Gravina, G. A., Chemistry, nitrogen and carbon stocks in different land-use systems in a tropical environment. Afr. J. Agric. Res., 10(7), 660-667.

22. Sharma, G., Sharma, R. and Sharma, E., Impact of stand age on soil $\mathrm{C}, \mathrm{N}$ and $\mathrm{P}$ dynamics in a 40 -year chronosequence of alder- cardamom agroforestry stands of the Sikkim Himalaya. Pedobiologia, 2009, 52, 401-414.

23. Shreenivas, B. V., Hebbara, M., Yeledhalli, N. A. and Ravi, M. V., Long-term effects of trees on soil properties in the saltaffected vertisol. J. Indian Soc. Soil Sci., 2010, 58, 413-417.

24. Lenka, N. K., Dass, A., Susama, S. and Patnaik, U. S., Soil carbon sequestration and erosion control potential of hedgerows and grass filter strips in sloping agricultural lands of eastern India. Agric. Ecosyst. Environ., 2012, 158, 31-40.

25. Paul, K. I., Polglase, P. J., Nyakuengama, J. G. and Khanna, P. K., Change in soil carbon following afforestation. For. Ecol. Manage., 2002, 168, 241-257.

ACKNOWLEDGEMENTS. This work was supported by a network project 'National Innovations on Climate Resilient Agriculture (NICRA)' of the Indian Council of Agricultural Research (ICAR), New Delhi.

Received 20 December 2017; revised accepted 30 August 2018

doi: $10.18520 / \mathrm{cs} / \mathrm{v} 116 / \mathrm{i} 1 / 112-116$

\section{Myco-potash solubilizers}

\author{
B. K. Parida ${ }^{1}$, R. V. Vyas ${ }^{2, *}$, Y. K. Jhala ${ }^{2}$ and \\ S. Dasgupta ${ }^{1}$ \\ ${ }^{1}$ Bhagwan Mahavir College of M Sc Biotechnology, \\ Surat 395 017, India \\ ${ }^{2}$ Department of Agricultural Microbiology, Anand Agricultural \\ University, Anand 388 110, India
}

This study was carried out to evaluate the efficacy of agriculturally beneficial fungi for potash solubilization and to develop myco-potash cultures for use in crop growth. In all six fungal cultures were utilized in the study, viz. Paecilomyces lilacinus, Tricoderma harzianum, Aspergillus wentii, Emericella nidulans, Verticillium lecanii and Tricoderma viride. Among them, $A$. wentii and $T$. viride were found to produce 3.3 and $3.65 \mathrm{~mm}$ solubilization index around the colony after 7 days of incubation (DAI) on Aleksandrov medium supplemented with mica as potash source. Whereas for agar medium supplemented with feldspar, maximum solubilization index was $2.5 \mathrm{~mm}$ (A. wentii), $2.55 \mathrm{~mm}$ (T. viride), $2.48 \mathrm{~mm}$ (V. lecanii) and $2.58 \mathrm{~mm}$ (P. lilacinus) 7 DAI. To reveal the mechanism of potash solubilization, $A$. wentii, $T$. viride, $T$. harzianum and $V$. lecanii were chosen for organic acid profiling using HPCL. $A$. wentii produced the highest amount of total organic acid $(1847.775 \mu \mathrm{g} / \mathrm{ml})$.

Keywords: Fungal cultures, myco-potash, organic acids, solubilization index.

*For correspondence. (e-mail: rajababuvyas@gmail.com) 